75 巻 756 号 $(2009-8)$

\title{
インデンテーション法による粘弾性特性の評価と 時間一温度換算則の適用*
}

\author{
坂 上 賢 一*1, 岡 崎 信 平*2, 小川武 史*1

\section{Evaluation of Viscoelastic Characteristics by Indentation Technique and Application of Time-Temperature Superposition Principle}

\author{
Kenichi SAKAUE*3, Shimpei OKAZAKI and Takeshi OGAWA \\ *3 Department of Mechanical Engineering, Aoyama Gakuin University, \\ 5-10-1 Fuchinobe, Sagamihara-shi, Kanagawa, 229-8558 Japan
}

\begin{abstract}
Indentation technique was applied to evaluate the viscoelastic characteristic of a polymeric material. In addition, time-temperature superposition principle was used to obtain the master curve of the viscoelastic characteristics. In the present stydy, load controlled indentation test with a Berkovich indenter was performed on Polypropylene (PP). The results showed that the measured penetration depth exhibits typical creep behavior of viscoelastic materials. The viscoelastic and plastic deformation can be separated from the measured penetration depth through the shape measurement of impression by using AFM. Creep compliance estimated by the viscoelastic deformation are in good agreement with that obtained by tensile creep test. Moreover, the master curves evaluated by indentation and tensile creep test were corresponding over a wide range of the reduced time. This fact means that indentation is useful technique for the measurement of viscoelastic characteristics of polymeric materials.
\end{abstract}

Key Words : Viscoelasticity, High Polymer Materials, Material Testing, Creep, Indentation, Creep Compliance, Time-Temperature Superposition Principle

\section{1. 序論}

高分子材料は, 優れた成形性および電気絶縁性等の 特徵から，工業界のあらゆる分野で利用されている。 しかし，高分子材料は粘弾性を有しており，その力学 特性は時間，温度に著しく依存する．そのため，高分 子材料を工業的用途で活用するためには，力学特性の 時間依存性を評価した上で製品の寿命予測などの信頼 性評価を行う必要がある。従来，粘弹性体の力学特性 評価は,クリープ試験などを長時間行うことによって 取得してきたが，近年では，試験片形状の制約が少な いインデンテーション試験によって粘弹性特性を取得 する試みがなされている(1) (10). また，インデンテー ション試験から粘弹性体の力学特性を評価寸るための 理論が構築されている(11) (13). しかし，信頼性評価 に有用な粘弹性特性の評価には至っていない。

粘弹性体の力学特性をインデンテーション試験に よって評価した多くの研究は, 粘弹性特性の評価に要 した時間が短く，その結果，製品の寿命予測などに必

* 原稿受付 2008 年 12 月 18 日.

*1 正員, 青山学院大学理工学部機械創造工学科( $\mathbf{e} 229-8558$ 相模原市淵野辺 5-10-1)

*2 正員, 青山学院大学大学院理工学研究科理工学専攻.

E-mail:sakaue@me.aoyama.ac.jp
要な $10^{4}$ 秒から $10^{6}$ 秒に及ぶ広い時間領域の粘弾性特 性の評価には至っていない. 一般的に，このような広 い時間領域の粘弾性特性を評価するには異なる温度で 得られる粘弾性特性に, 時間一温度換算測を適用して マスター曲線をつくる(16). しかしながら，インデン テーション試験からマスター曲線を構築する方法につ いては研究されていないばかりか, インデンテーショ ン法を用いて異なる温度における高分子材料の粘弹性 特性を取得した例はほとんどない。

さらに，広い時間領域の粘弾性特性を評価する場合 には, 粘弹性体の力学特性が大きく変化する温度条 件下，才なわちクリープや応力緩和の時間依存性が顕 著な条件下でインデンテーション試験を行う必要があ る.しかし, 既存の研究では, 時間依存性が小さいポ リカーボネートやPMMA などの粘弾性特性を室温下 で評価したものが多く, 粘弾性体の力学特性が大きく 変化する温度条件下でインデンテーション試験が有効 であるか否かは確かめられていない，このようなこと から，インデンテーション試験によって，数析に及ぶ 広い時間領域の粘弾性特性を取得する方法については 確立されていない.

本研究は，粘弹性体にインデンテーション試験を行 


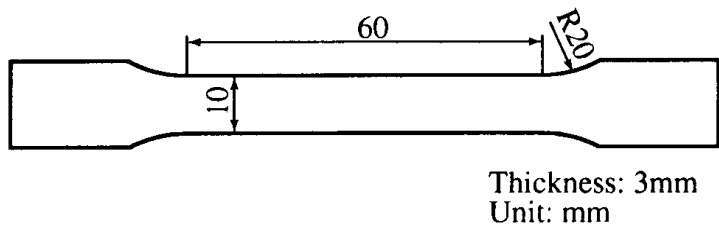

Fig. 1 Specimen geometry for tensile creep test.

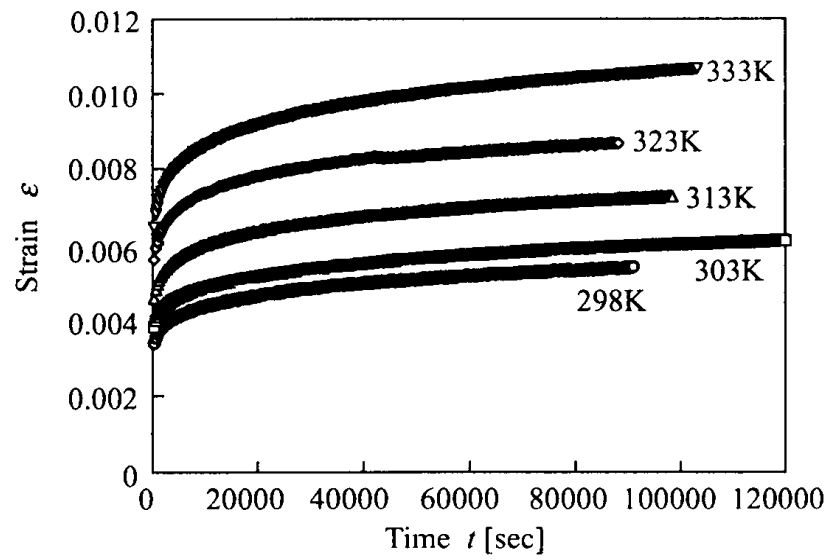

Fig. 2 Time variations of strain mesured by creep tests.

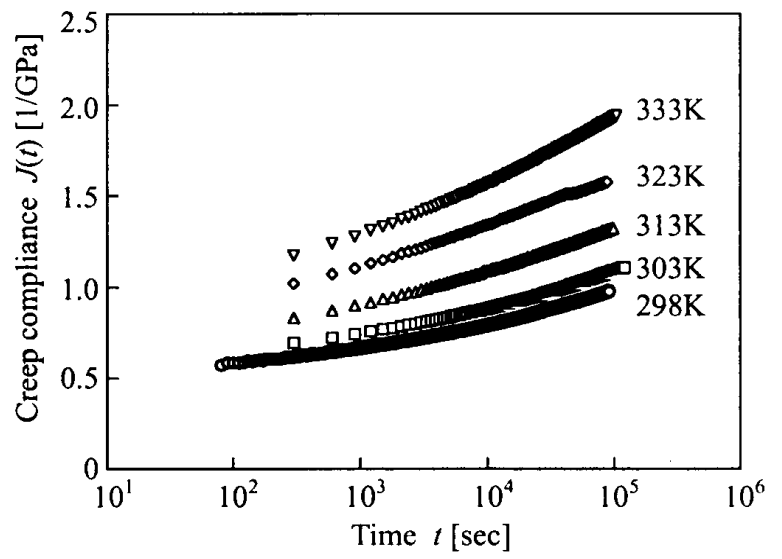

Fig. 3 Creep compliaces of the test material at different temperature measured by tensile creep tests.

い, 単軸引張クリープ試験によるクリープコンプライ アンスと同じ粘弾性特性を評価する方法について示す ものである. 一連の結果から，インデンテーション試 験で求められたクリープコンプライアンスに時間一温 度換算則が適用できる場合，広い時間領域にわたって 粘弾性特性を取得できることを示す.

\section{2. 供試材の単軸引張における粘弾性特性}

供試材は，市販のポリプロピレン樹脂 (Polypropylen, PP) であり，厚さ $3 \mathrm{~mm}$ の板状に成形されたもの

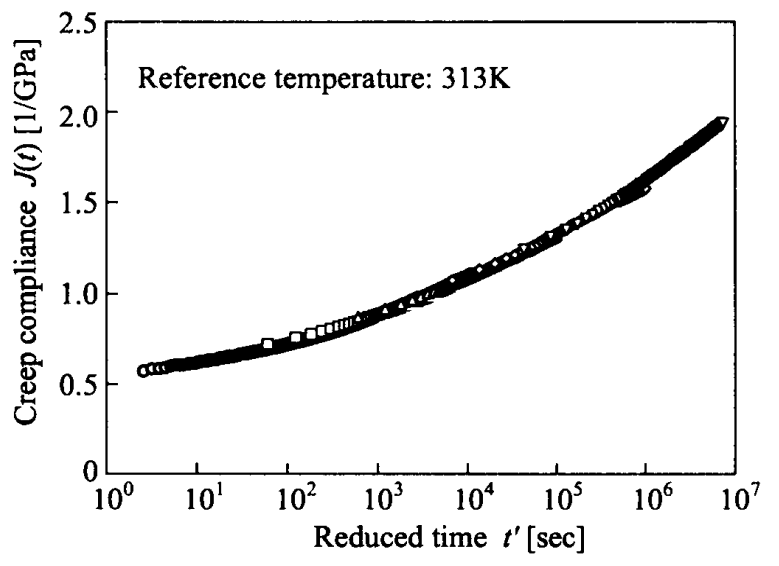

Fig. 4 Master curves of creep compliaces based on the reference temperature of $313 \mathrm{~K}$.

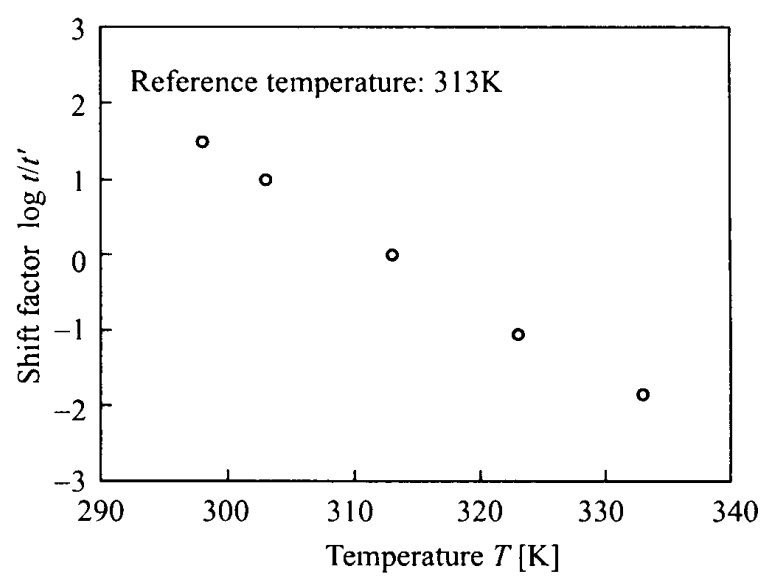

Fig. 5 Time-temperature shift factor of the test material.

を使用した。この供試材の単軸負荷下における粘弾性 特性を得るため, 引張試験片を図 1 の形状に加工した. 加工した試験片には成形時の残留応力を除去するため の熱処理を施した，熱処理は，353Kで 12 時間保持し た後，6時間かけて室温まで炉冷した。

供試材の粘弾性特性は, 単軸引張クリープ試験に よって得られるクリープコンプライアンスから評価し た.クリープ試験では 5.5MPa のステップ荷重を，試 験片の長手方向に加えた。これらの試験片に生じるひ ずみはひずみゲージ(ゲージ長 : $2 \mathrm{~mm})$ を用いて測 定した。クリープ試験によって得られたひずみ の時 間変動を図 2 に示す。また，得られた供試材のクリー プコンプライアンス $J(t)=\varepsilon(t) / \sigma(\sigma:$ 応力 $)$ を図 3 に 示す.これらの図中には, $298 \mathrm{~K}$ から $333 \mathrm{~K}$ までの各 温度で引張クリープ試験によって得られた結果が示さ れている。

図 4 は, 図 3 の $J(t)$ に時間一温度換算則を適用し て得られる基準温度 $T_{0}=313 \mathrm{~K}$ のマスター曲線を示し 


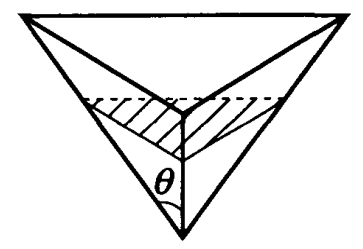

(a)

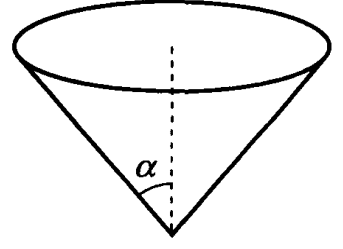

(b)
Fig. 6 Geometry of indenters.

(a) Berkovich indenter. (b) Conical indenter.

ている，マスター曲線の構築には，図 5 の時間一温度 移動因子を使用した，図 4 に示寸ように，供試材のク リープコンプライアンスは $10^{7}$ 秒までの時間領域に至 るまで 3 倍程度変化し, 明確な時間依存性を示寸。

\section{3. クリープコンプライアンスの評価方法}

インデンテーション試験では, 一般的に, 図 6(a)の ような三角錐压子を材料表面に押込み，押込み力 $F$ と 押込み深さ $h$ を連続的に取得して材料の力学特性を評 価する。この三角錐圧子は押込み深さ之投影面積の関 係が等しい円錐圧子 (図 6(b)) と見なすことができる (14).そのため，三角錐圧子を用いたインデンテーショ ン試験から粘弾性体の特性係数を評価する際の基礎式 は, Sneddonによる円錐圧子押込み問題の弾性解 ${ }^{(15)}$ と, 線形弹性問題と線形粘弹性問題との対応原理 ${ }^{(16)}$ によって与えられる.

剛体の円錐圧子を弾性体平面に押込むとき，押込み 力 $F$ と押込み墚さ $h$ の関係は次式で与えられる.

$$
h^{2}=\frac{\pi\left(1-\nu^{2}\right) \cot \alpha}{2 E} F
$$

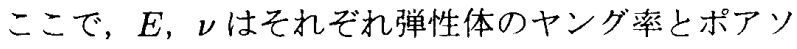
ン比， $\alpha$ は図 6(b) に示す円錐圧子の角度である. 式 (1) の弹性解と対応原理から, 剛体の円錐圧子を粘弾 性体平面に押込むときの関係式は次式で与えられる。

$$
h^{2}(t)=\frac{\pi\left(1-\nu^{2}\right) \cot \alpha}{2} \int_{-\infty}^{t} J(t-\tau) \frac{d F(\tau)}{d \tau} d \tau
$$

ここで, $J(t)$ は粘弾性体のクリープコンプライアン ス, $F(t)$ は押込み力であり，ともに時間の関数で与え られる。

インデンテーション試験の負荷形式としてステップ 負荷を用いる場合，押込み力 $F(t)$ はステップ保持力 $F_{0}$ とステップ関数 $H(t)$ を用いて $F(t)=F_{0} H(t)$ で 表わされる。これを式 (2)に代入することで，クリー プコンプライアンス $J(t)$ は

$$
J(t)=\frac{2}{\pi\left(1-\nu^{2}\right) F_{0} \cot \alpha} h^{2}(t)
$$

となる。 (a)

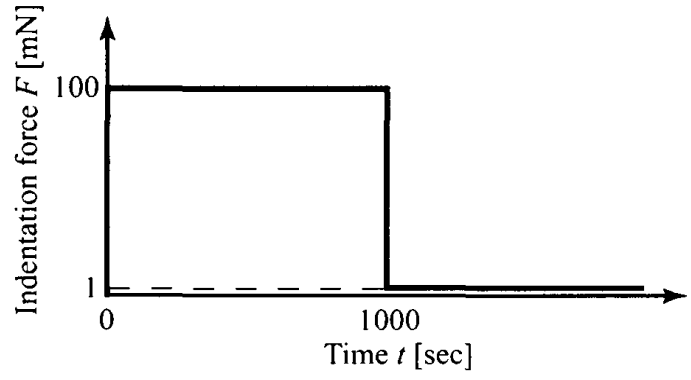

(b)

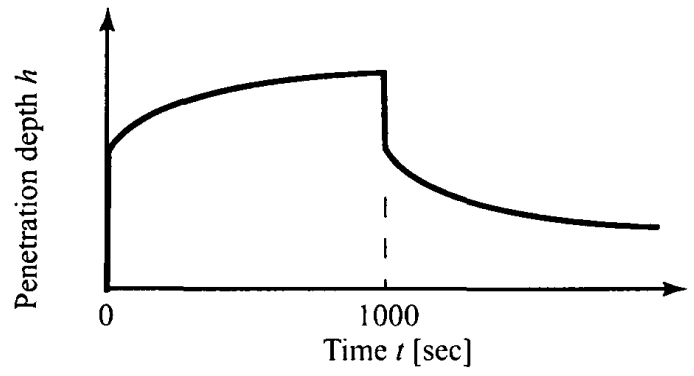

Fig. 7 Schematic diagram of (a) input indentation force and (b) respose penetration depth.

\section{4. 試 験 方 法}

本研究では，インデンテーション試験機に(株) 島津 製作所製高温超微小硬度計 DUH-W201 を使用する. 圧子には，図 6(a) に示寸稜間角 $\theta$ が $115^{\circ}$ の三角錐压 子 (バーコビッチ圧子) を用いる。この三角錐圧子と 等価な円錐圧子 (図 6(b)) の $\alpha$ は $70.3^{\circ}$ である。試験 片には，引張試験に使用した材料から厚さ $1.5 \mathrm{~mm} に$ 研磨したものを使用した。試験片表面には温度測定の ため，素線径 $0.2 \mathrm{~mm}$ の熱電対を取り付けた.

インデンテーション試験の負荷形式は, 図 7(a) の ようなステップ負荷である. ステップ保持力 $F_{0}$ は $100 \mathrm{mN}$ ，保持時間は約 1000 秒，ステップ負荷の立ち 上がり時間は約 8 秒である. 負荷保持後は約 8 秒間か けて除荷し, その後, 試験機のドリフト補正機能によ り微小な押込み力 $1 \mathrm{mN}$ を約 1000 秒間保持する.

このような試験を行ったときの，粘弾性体の押込み 深さ $h$ の時間変動を図 7(b) に示寸，ステップ負荷後 の押込み力保持部では，時間とともに $h$ が増大寸るク リープ変形が現れる。一方，除荷後の微小な押込み力 の保持部では，時間とともに $h$ が減少していく．式 (3) によるクリープコンプライアンスの評価は，ステップ 負荷直後の押込み力保持部から行う.

先端が鋭利な三角錐圧子によるインデンテーション 試験では，押込み力が小さい場合においても，塑性変 形により試験片表面に圧痕が付与される。 そのため, 実際の試験で計測される押込み深さは粘弾性変形と塑 性変形の和となる。一方, クリープコンプライアンス の評価に用いる式 $(3)$ では，負荷により生じる押込み 


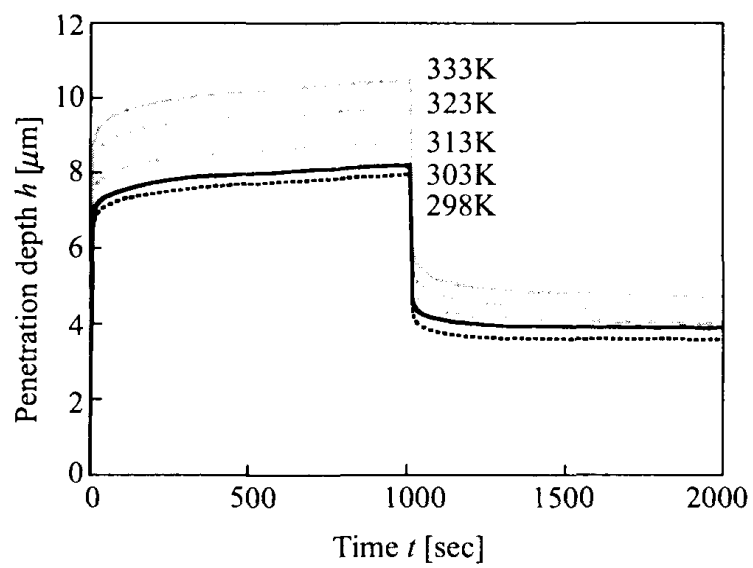

Fig. 8 Time variation of penetration depth at various temperature conditions.

媣さは全て粘弾性変形によるものと仮定している，し たがって, 式 (3) からクリープコンプライアンスを評 価するには，計測された押込み梁さから塑性変形量を 引いた粘弾性変形のみを求める必要がある。本研究で は，塑性変形量の推定を試験後の圧痕形状から行う。 圧痕形状の計測に用いる原子間力顕微鏡 (AFM) には, (株) キーエンス製ナノスケールハイブリッド顕微鏡 VN-8000を使用寸る.

本研究では, インデンテーション試験から得られた 結果に時間一温度換算則を適用し，広い時間領域にわ たってクリープコンプライアンスを求めるため，試験 は異なる温度条件で行う。各温度条件でインデンテー ション試験は 5 回行い, それらの結果から押込み深さ $h$ と時間 $t$ の関係 $(h-t$ 曲線) の平均的な試験結果を求 める. その後, その平均的な試験結果とほぼ同じ $h-t$ 曲線が得られるまで試験を繰り返し，得られた試験に ついて AFM を用いた圧痕形状の計測を行う。時間一 温度換算則の観点から, 各温度の物理時間において試 験後の経過時間を等しくするため, インデンテーショ ン試験後の試験片は試験条件之同じ温度に保った恒温 槽内で保管する．また，圧痕形状計測のために恒温槽 から取り出寸時間は, 最大 15 分とした。

\section{5. 試 験 結 果}

$5 \cdot 1$ 押込み深さ・圧痕形状の時間変化図 8 にイ ンデンテーション試験から得られた押込み深さ $h$ と時 間 $t$ の関係 $(h-t$ 曲線)を示す. 図 8 からわかるように, $100 \mathrm{mN}$ の押込み力保持部では $h$ が増大寸るクリープ 変形が発生し, 除荷後, $1 \mathrm{mN}$ の微小な押込み力の保 持部では時間とともに $h$ が回復する現象が現れてい る.また，温度が高くなるにしたがって，hが増加し ていることがわかる、試験終了時に大きく $h$ が残留し
ているのは，塑性変形によるものである.

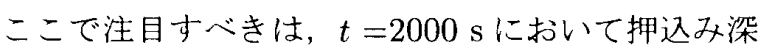
さが依然として変化しており, 定常状態に至っていな いことである.この挙動は, 温度が高くなるにつれ顕 著になる。これは，ステップ負荷の保持時間と同程度 の時間では粘弹性による変形は完全に回復しないこと を意味している。

AFM を用いた圧痕形状計測結果の一例として， $313 \mathrm{~K}$ の結果を図 9 に示す. 図 9(a) は試験終了から 15 分後の形状, 図 $9(\mathrm{~b})$ は 24 時間後の形状であり，そ れぞれ高さの空間微分表示と圧痕の稜線に沿った断面 の高さ分布を示している，図からわかるように，圧痕 の最大深さが試験 15 分後は $2.70 \mu \mathrm{m}$ であるのに対し， 24 時間後は $2.43 \mu \mathrm{m}$ であり, 試験終了後 15 分から 24 時間の間，明らかに押込み深さが回復していることが わかる。

$\mathrm{AFM} に よ り$ 計測した圧痕の最大深さの時間変動を 図 10 に示す。 どの試験温度においても，試験終了か ら 24 時間経過した後の圧痕最大深さは，ほとんど変 化していないことから，24時間経過した時点で粘弾 性による押込み深さの回復は完了したと考えられる. したがって，24 時間経過後の圧痕の最大深さから, 図 8 に示した $h-t$ 曲線において粘弾性変形のみの押込み 深さがわかる。図 10 は, 圧痕最大深さは温度が高く なるにしたがって，わずかに増加している。このこと は，使用した供試材の降伏条件が温度に依存すること を意味している。

$5 \cdot 2$ クリープコンプライアンス AFM を使用 した圧痕形状の計測によって $h-t$ 曲線の粘弾性変形成 分が求められることから, 式 (3) を用いたクリープコ ンプライアンスの評価が可能になる。 $h-t$ 曲線の押込 み力保持部の押込み深さと長時間経過後の圧痕最大深 さとの差を, 式 (3)に代入することで得られたクリ一 プコンプライアンス $J(t)$ を図 11 に示す。ここで, 長 時間経過後の圧痕最大深さは図 $10 の 24$ 時間経過後 の值を用いた。図 11 には, 図 3 のデ一夕を併記して ある. 各試験温度において，引張試験とインデンテー ション試験によって取得された $J(t)$ は一つの同じ曲 線上にプロットされていることがわかる.このことか ら，インデンテーション試験によって, $J(t)$ を正しく 評価できたといえる.

インデンテーション試験によって得られた $J(t) に$ 対し，時間一温度換算則を適用して得られるマスター 曲線を図 12 に示す。 また，その際に使用した時間一 温度移動因子を図 13 に示寸。これらの図中には引張 試験によって得られた結果を併記してある。网 12,13 
(a)
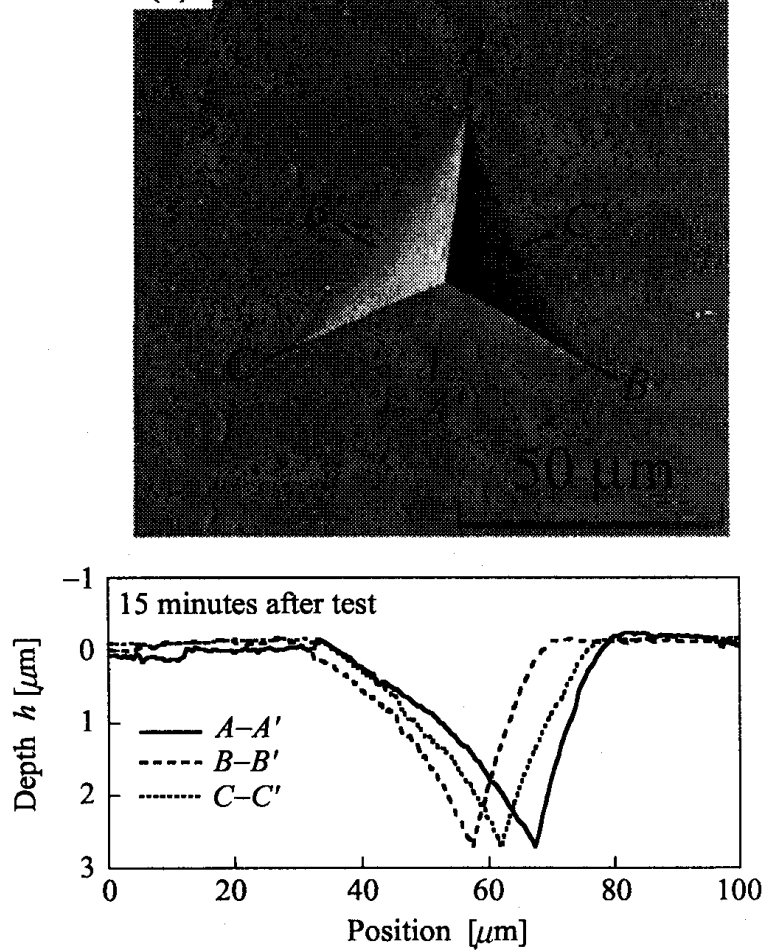

(b)
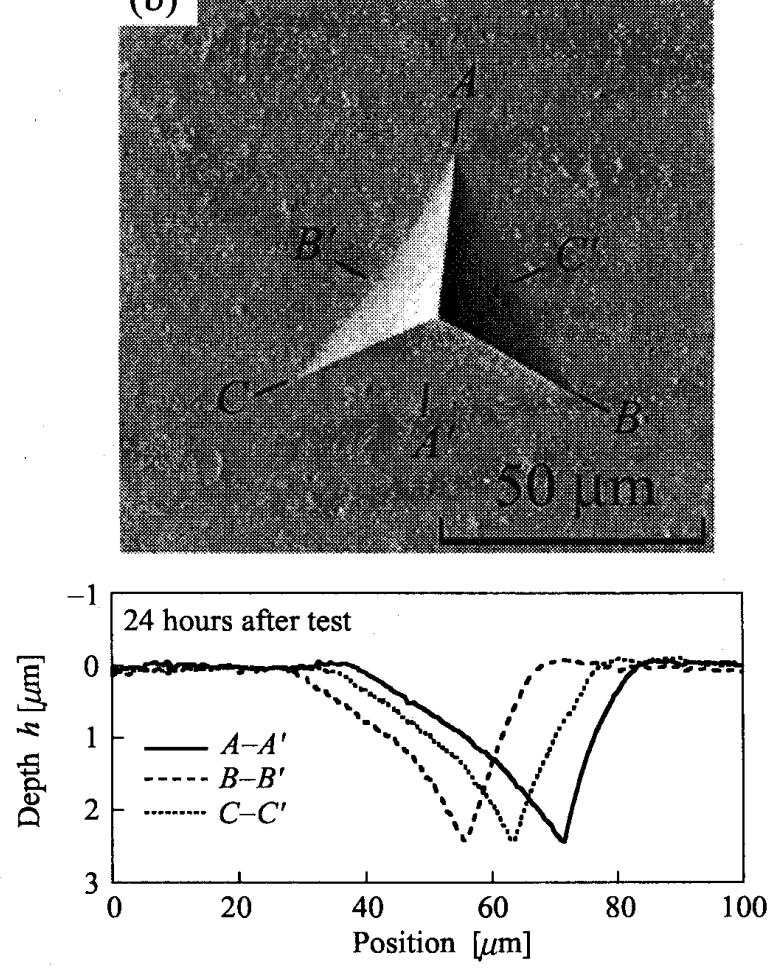

Fig. 9 Shapes of impressions measured by AFM (a) at 15 minuits and (b) at 24 hours after indentation test at a temerature of $313 \mathrm{~K}$.

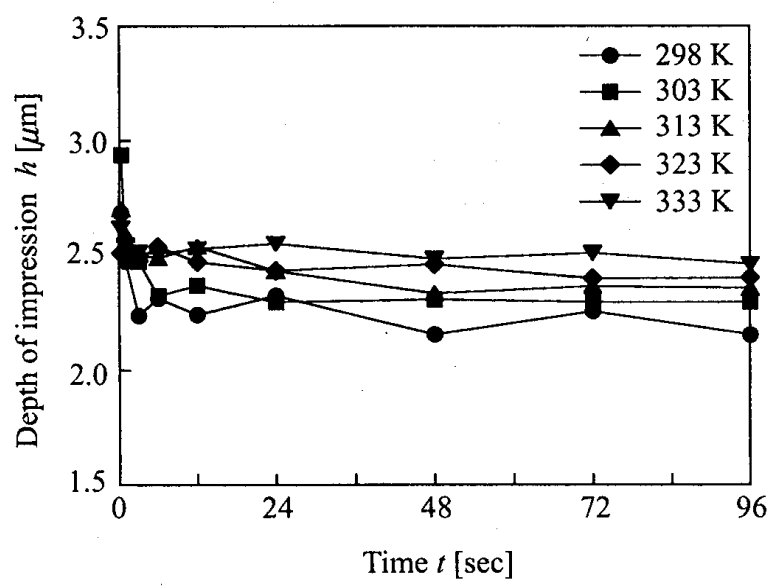

Fig. 10 Time variation of the maximum depth of impressions after indentation test.

から，インデンテーション試験によって引張試験とほ ぼ同じマスタ一曲線が取得できることがわかる。

本研究では, インデンテーション法によるクリープ コンプライアンスの評価に際し，計測された押込み深 さから压痕深さを引くことで, 粘弾性変形のみの押込 み深さを求めた。このような方法で，粘弾性変形のみ の押込み深さが正しく評価できる場合，熱可塑性樹脂・ 熱硬化性樹脂のいずれについても，インデンテーショ

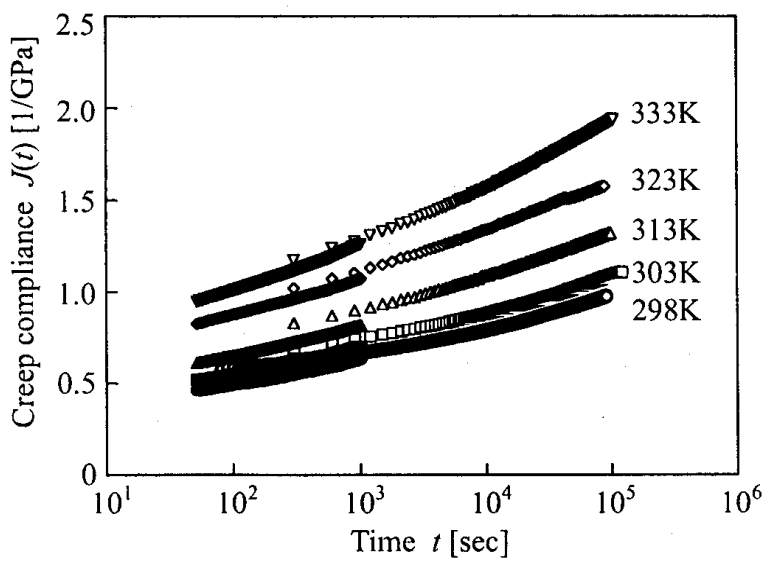

Fig. 11 Creep compliaces of the test material at different temperatures measured by indentation tests.

ン試験は粘弾性特性の評価に対して有用な方法である といえる.

\section{6. 結 論}

インデンテーション試験中の粘弹性変形を, 押込み 深さの時間変動と試験後の圧痕深さから正確に評価寸 ることができる場合，インデンテーション試験によっ てクリープコンプライアンスを求めることができる. 


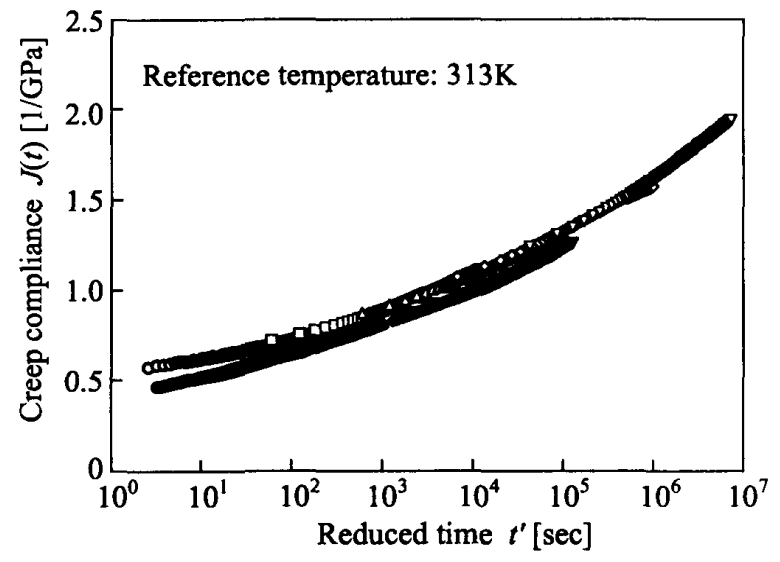

Fig. 12 Master curve of creep compliance estimated by indentation tests.

さらに，時間一温度換算則が適用できる場合，引張ク リープ試験とほぼ同じマスター曲線を取得することが できる.これらの結果は、インデンテーション試験が 粘弾性体のマスター曲線取得に対して有用な方法であ ることを示している.

\section{文献}

(1) Cheng, L. Xia, X., Yu, W., Scriven, L.E. and Gerberich, W.W., Flat-punch indentation of viscoelastic material, J. Polym. Sci. Pol. Phys., Vol.38, No.1, (2000), pp.10-22.

(2) Lu, H., Wang, B., Ma, J., Huang, G. and Viswanathan, H., Measurement of creep compliance of solid polymers by nanoindentation, Mech. TimeDepend. Mater., Vol.7, No.3-4, (2003), pp.189-207.

(3) Oyen, M.L. and Cook, R.F., Load-displacement behavior during sharp indentation of viscous-elasticplastic materials, J. Mater. Res., Vol.18, No.1, (2003), pp.139-150.

(4) Huang, G., Wang, B. and Lu, H., Measurements of viscoelastic functions of polymers in the frequency-domain using nanoindentation, Mech. Time-Depend. Mater., Vol.8, No.4, (2004), pp.345364.

(5) Odegard, G.M., Gates, T.S. and Herring, H.M., Characterization of viscoelastic properties of polymeric materials through nanoindentation, Exp. Mech., Vol.45, No.2, (2005), pp.130-136.

(6) Huang, G. and Lu, H., Measurement of Young's relaxation modulus using nanoindentation, Mech. Time-Depend. Mater., Vol.10, No.3, (2006), pp.229. 243.

(7) Oyen, M.L., Analytical techniques for indentation of viscoelastic materials, Philos. Mag., Vol.86, No.33 35 , (2003), pp.5625-5641.

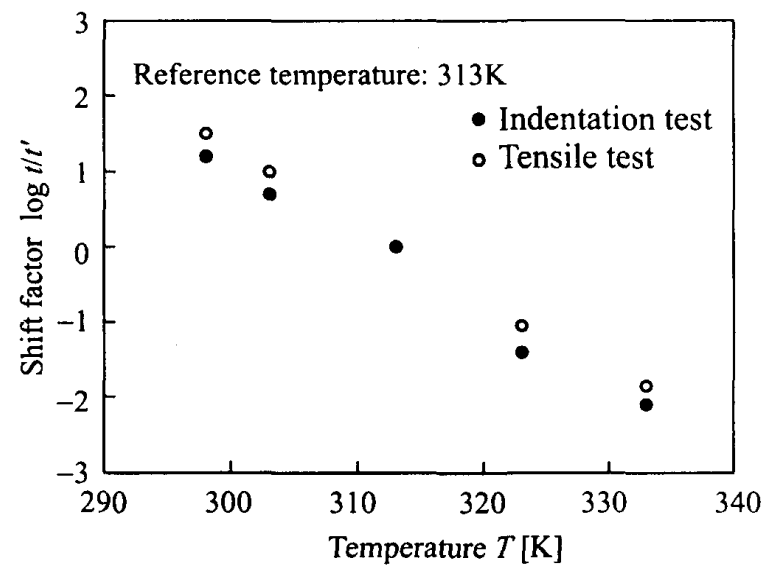

Fig. 13 Time-temperature shift factor for the estimation of the master curve in Fig. 13.

(8) Schffmann, K.I., Nanoindentation creep and stress relaxation tests of polycarbonate: Analysis of viscoelastic properties by different rheological models, Int. J. Mater. Res., Vol.97, No.9, (2006), pp.1199-1211.

(9) Huang, G and Lu, H., Measurements of two independent viscoelastic functions by nanoindentation, Exp. Mech., Vol.47, No.1, (2007), pp.87-98.

(10) Oyen, M.L., Sensitivity of polymer nanoindentation creep measurements to experimental variables, Acta Materialia, Vol.55, No.11, (2007), pp.3633-3639.

(11) Cheng, Y.-T., and Cheng, C.-M., General relationship between contact stiffness, contact depth, and machanical properties for indentation in linear viscoelastic solids using axisymmetric indenters of arbitrary profiles, Appl. Phys. Lett., Vol.87, No.11, (2005), 111914.

(12) Cheng, Y.-T., Wangyang, N. and Cheng, C.M., Nonlinear analysis of oscillatory indentation in elastic and viscoelastic solids, Phys. Rev. Lett., Vol.97, No.7, (2006), 075506.

(13) Liu, C.-K., Lee, S., Sung, L.-P. and Nguyen, T., Load-displacement relations for nanoindentation of viscoelastic materials, J. Appl. Phys., Vol.100, No.3, (2006), 033503.

(14) Fischer-Cripps, A.C., Nanoindentation Second Edition, (2004), Springer.

(15) Sneddon,I.N., The relation between load and penetration in the axisymmetric Boussinesq problem for a punch of arbitrary profile, Int. J. Eng. Sci., Vol. 3, (1965), pp.47-57.

(16) Christensen, R.M., Theory of Viscoelastitcity Second Edition, (2003), Dover. 